\begin{tabular}{|l|c|c|c|}
\hline & & $23-37$ & Hannover 1998 \\
\hline
\end{tabular}

\title{
Surface geometry of the Last Glacial Maximum (LGM) in the southeastern Swiss Alps (Graubünden) and its paleoclimatological significance
}

\author{
DURI FLORINETH*) \\ Last Glacial Maximum, Swiss Alps, trimlines, flowdirection, modelling, \\ paleoglaciology, paleoclimatology
}

\begin{abstract}
Using detailed field evidence provided by trimlines on former nunataks, erratic boulders and the orientations of glacial striae, the surface geometry in the accumulation area during the Last Glacial Maximum was reconstructed for the area of SE Switzerland and adjacent Italy. Collectively, the trends of trimline elevations, flowlines deduced from glacial striae and bedrock morphology along the longitudinal valleys and their tributaries indicate that the former accumulation area consisted of an ice dome with the ice divide located over the area enclosed by Schlarignia, Cinuos-chel, Livigno and Piz Bernina. It attained a minimum altitude of approximately $3000 \mathrm{~m}$. Modelling the topography of the ice surface using a Geographical Information System (GIS) is consistent with these results.

The paleoclimatological signal included in this surface geometry was used to draw conclusions about the main atmospheric paleocirculation patterns and to outline the principal precipitation areas for the Alps during the last glaciation. It followed from this that ice build-up was principally related to dominating precipitation by southerly circulation (foehn). The prevaleance of foehn circulation most likely reflects a southward shift of the North Atlantic polar atmospheric front and of the accompanied storm track due to the advancing margin of sea ice.

There exists good agreement between these assumptions and (a) results of global circulation models for the time of the LGM; (b) estimations of basal shear stress values and flow velocities for Ice Age glaciers; and (c) interpretations of paleowind indicators.
\end{abstract}

[Die Oberflächengeometrie des letzteiszeitlichen Maximums (LGM) in den südöstlichen schweizer Alpen (Graubünden) und ihre paläoklimatologische Bedeutung]

Kurzfassung: Anhand detaillierter Feldbefunde, wie z.B. Schliffgrenzen an ehemaligen Nunatakern, der Verteilung erratischer Blöcke und der Orientierung von Gletscherschrammen, wurde die Oberflächengeometrie des Akkumulationsgebietes des letzteiszeitlichen Maximums im Gebiet Südostschweiz und Norditalien rekonstruiert. Der Höhenverlauf der Schliffgrenzen, die aus den Striemungsdaten abgeleiteten Fließbewegun-

\footnotetext{
*) Adress of the Author: D. Florineth, Geologisches Institut, Universität Bern, Baltzerstrasse 1, CH-3012 Bern, Switzerland.
}

gen des Eises, und die Morphologie des Felsuntergrundes entlang der Haupt- und Seitentäler deuten darauf hin, daß das ehemalige Akkumulationsgebiet aus einem Eisdom bestand. Die Eisscheide lag dabei über dem von Schlarignia, Cinuos-chel, Livigno und Piz Bernina eingeschlossenen Gebiet und erreichte eine minimale Höhe von ca. 3000 m. Diese Resultate konnten durch eine Modellierung der Topographie dieser Eisoberfläche mit Hilfe eines Geographischen Informationssystems (GIS) bestätigt werden.

Das Klimasignal, welches in dieser Gletschergeometrie enthalten ist, wurde anschließend genutzt, um vorherrschende atmosphärische Zirkulationsmuster und die daraus resultierenden Hauptniederschlagsgebiete in den Alpen während des letzten Hochglazials zu bestimmen. Es läßt sich daraus folgern, daß für den Aufbau des Eisdomes vorwiegend Niederschläge von Südstaulagen verantwortlich waren. Die Dominanz der Südstaulagen ist eine direkte Folge der vorrückenden Meereisgrenze im Nordatlantik. Letztere bedingte eine Verlagerung der atmosphärischen Polarfront und der damit verbundenen Hauptzugbahn zyklonaler Störungen um bis zu $20^{\circ}$ südwärts.

Diese Ergebnisse korrespondieren gut mit (a) den Resultaten globaler Zirkulationsmodelle für das LGM; (b) Schätzungen der basalen Schubspannungen und der Fliessgeschwindigkeiten für die Eiszeitgletscher; und (c) mit der Interpretation von Paläowind-Indikatoren.

\section{Introduction}

Paleoglaciological reconstructions are usually done by means of mapping geological and geomorphological depositional features in the areas below the equilibrium line altitude (ELA), and of erosional features in the former accumulation area. Detailed field evidence in the former ablation area and recent progress in the field of computer technology has led to increasing interest in numerical modelling and reconstructing Pleistocene Alpine glaciers, especially in connection with the following questions: (a) the maximal extent of the former piedmont lobes (KELLER 1988), (b) the stratigraphic correlation of the different advances (PENCK \& BRÜCKNER 1909; HANTKe 1980; 


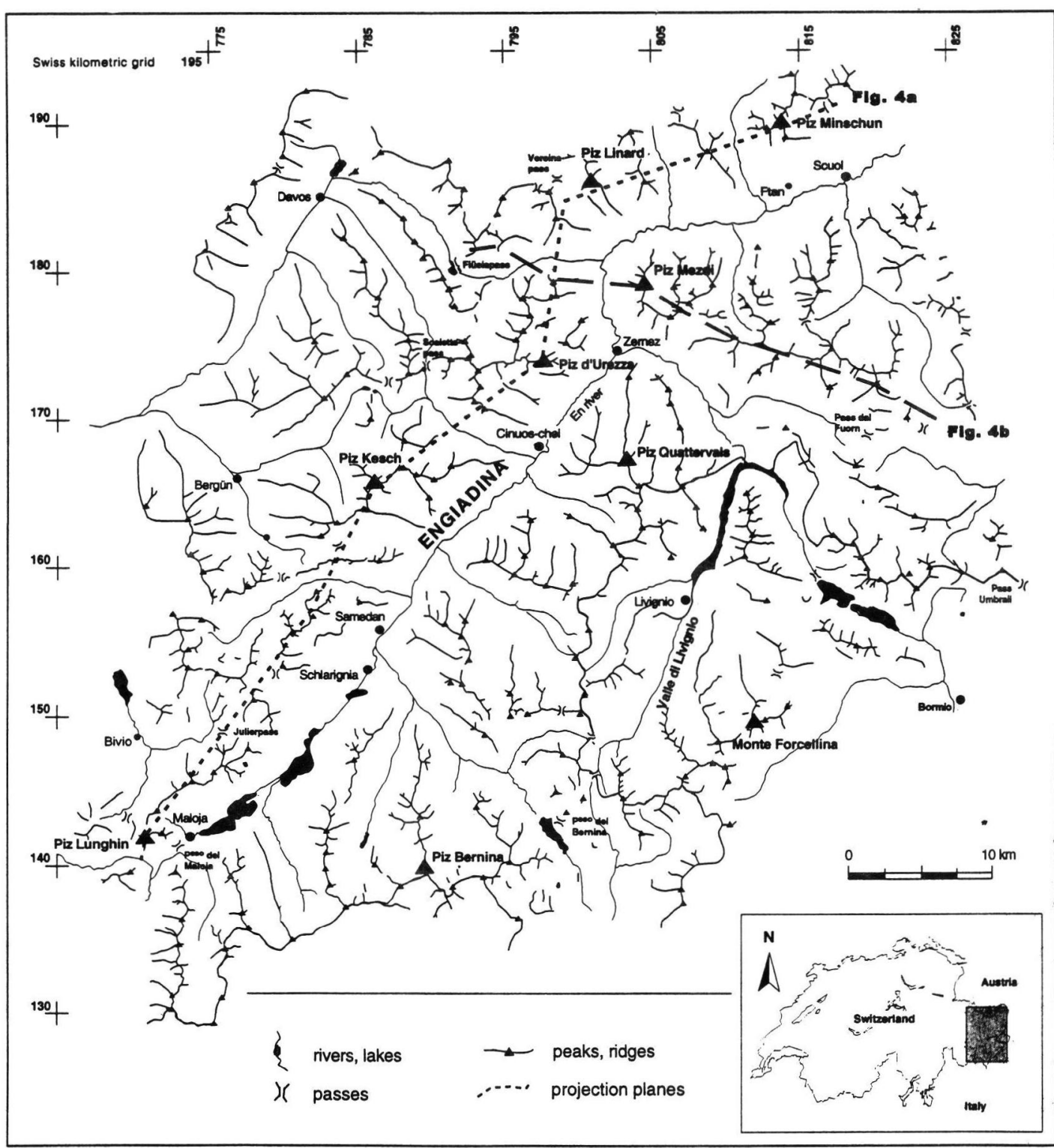

Fig. 1: Index map of southeastern Switzerland (Graubünden), northeastern Italy and western Austria with the locations mentioned in the text. Dashed lines give positions of cross - sections (Figs. $4 \mathrm{a}$ and 4b).

Abb. 1: Geographische Übersichtskarte der Südostschweiz und der angrenzenden Gebiete Italiens und Österreichs mit den im Text erwähnten Lokalitäten. Die Profilspuren der Fig. 4A und 4B sind ebenfalls angegeben.

SCHLÜCHTER 1991), (c) estimations of paleoglaciological parameters (BlatTer \& HAEBerLi 1984), (d) the geological evidence for glacier modelling (HAEBERLI \& SCHLÜCHTER 1987) as well as (e) conclusions about prevailing paleoclimatic conditions (HAEBERLI 1991a, 1991b). JÄCKLI (1962, 1970) compiled a detailed map of the Last Glacial Maximum (LGM) for all of Switzerland mostly from local investigations. The map published by Van HuSEN (1987) covers the LGM in the Eastern Alps and their forelands. Despite some uncertainties (Rhein glacier, [KeLLer 1993] southern Switzerland [BinI 1987; FelBer 1993]) these survey maps still rank as some of the best reconstructions, particularly with respect to the accumulation area. It is true that paleoglaciological modelling has experienced significant progress in recent years, but the geometry of former glaciers and ice-sheets nevertheless remains uncertain in the area above the ELA. As the accuracy of each (paleo)glaciological 
reconstruction is only as reliable as the geologi$\mathrm{cal} /$ geomorphological input data, the basic problem of modelling former ice bodies is given by the limited field evidence (overprinting by younger glacier advances, weathering, burial by snow and sediments, etc.) in the former accumulation area. Thus, due to the results acquired in the ablation area, the geometry of the alpine Ice Age glaciers was generally assumed to be strongly related to the present river system, i.e. ice-flow being the same as today's rivers. This hypothesis seems to be correct for the ablation area where minor variations in bed topography channelled the massive valley glaciers and stream flow of the ice predominated. The assumption, however, appears less valid at high altitudes in the central Alps, because mapping of glacial-erosion features indicate up-valley flow of some Ice Age glaciers, and ice transfluency over high altitude passes. Such features are in disagreement with existing reconstructions of the LGM. It is therefore evident that a realistic geometry of the last glacial ice body cannot be achieved by applying the conclusions drawn from investigations in the well-documented Swiss Plateau and Prealpes to the poorly understood inner alpine area.

The aim of this research project is to improve our understanding of the altitude and topography of the accumulation area during the LGM using geological and geomorphological evidence. Special interest is focused on (a) reconstructing flowlines of the ice at the LGM by mapped ice flow patterns, (b) modelling the ice surface in the former accumulation area by trimline evidence and (c) the possibilities to draw paleoclimatic conclusions from the shape of the former accumulation area.

\section{Field area}

Detailed mapping of glacial-erosion features in the central Alps of eastern Switzerland has alrea$\mathrm{dy}$ been carried out. The area described here is situated in the easternmost part of Graubünden (Switzerland) and adjacent Italy (Fig. 1).

This region is characterised by two large, southwest - northeast striking valleys (Engiadina and Valle di Livigno), emptying to the northeast and situated at a mean altitude of $1500-1700 \mathrm{~m}$. The gradient of these longitudinal valleys is low, while the shorter tributaries are rather steep. On both sides of these valleys the peaks of the different massifs have an average altitude of $2900-3400 \mathrm{~m}$, while the Bernina massif in the southwest reaches an elevation of 3500 - $4000 \mathrm{~m}$. Despite a very con- tinental climate with a mean annual precipitation amounting to just some $70-90 \mathrm{~cm}$ per year, the highest parts of these mountains remain glaciated today.

The bedrock geology of the area, described by various authors (e.g. SPITZ \& DYHRENFURTH 1914; CORNelius 1935; BÖSCH 1937; HeIERLi 1955; TrüMPY 1960; SpILLmann 1993) is important to the present study because most of the glacial history is inferred from erosional traces on bedrock. This area exposes Penninic nappes in the west (MargnaSella nappe and Platta nappe) and east (Tasna nappe), overlain by a stack of Austroalpine nappes (Fig. 2). The latter comprise the Upper Austroalpine Silvretta nappe (para- and orthogneisses, amphibolites) to the north, the S-charl-, Quattervals and Ortler nappes (Triassic and Jurassic sediments) to the east and the Campo/Languard nappe (gneisses) to the southeast as well as the Lower Austroalpine Err- and Bernina nappes (crystalline basement and Mesozoic sediments) to the southwest.

\section{Mapping results \\ Glacial-erosion features and erratics}

Fig. 3 shows the main localities of mapped glacial erosional features, including trimlines, striations, glacial polish, crescentic fractures and gouges as well as roches moutonnées. These features are scattered between the bottoms of the valleys and the trimline, superimposed on glacially-moulded bedrock. Glacial polish was found in only a few sites such as passes where ice-flow was constricted. The state of preservation of glacial polish and striae is highly dependent on the bedrock lithology. Fine grained igneous rocks preserve striations well, while carbonate rocks, slates and gneisses do not hold striations because of comparetively rapid physical weathering by granular disintegration or exfoliation.

The possibility of measured features being influenced by younger glacier advances was avoided by restricting the field survey to peaks and ridges near the trimline and to passes outside the moraines of the Younger Dryas.

In the region of Passo del Maloja $(1815 \mathrm{~m})$ striations, chattermarks and roches moutonnées occur on the glacially-moulded gneissic bedrock of the Margna-Sella nappe, but they are not common. Directly at the hospice, P-forms as well as numerous potholes can be found. Ice-flow direction was up-valley, towards southwest to west, as can be derived from striations and stoss-and-lee features. Erratics in the pass area from the Err- and 


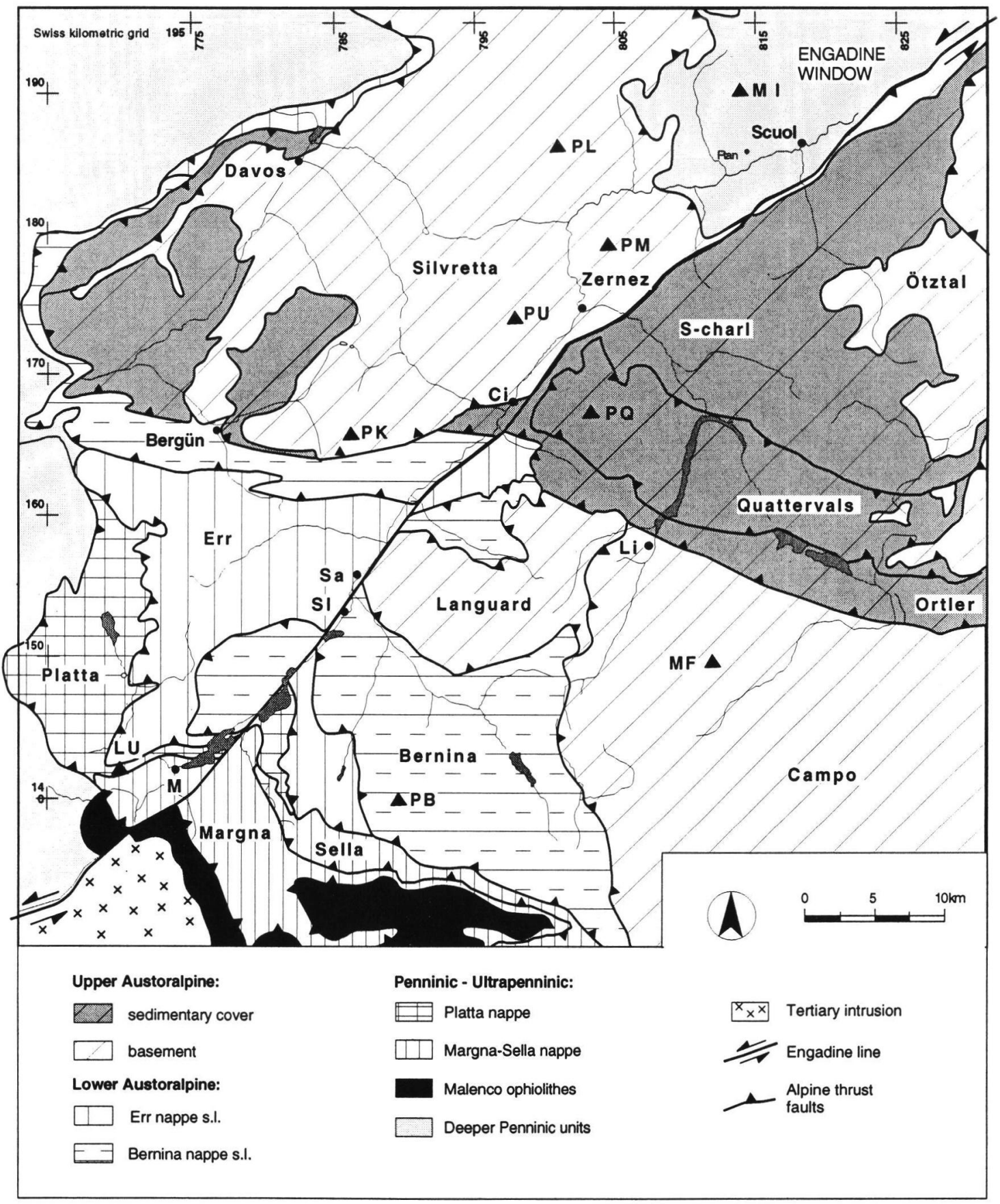

Fig. 2: Tectonic map of Austroalpine and Penninic nappes of the study area and of the Engadine Line, areal cover as Fig. 1; after Froitzheim \& Manatschal (1996), slightly modified.

Abbreviations: Ci - Cinuos-chel, Li - Livigno, M - Maloja, MF - Monte Forcellina, MI - Piz Minschun, LU - Piz Lunghin, PB - Piz Bernina, PK - Piz Kesch, PL - Piz Linard, PM - Piz Mezdi, PQ - Piz Quattervals, PU - Piz d'Urezza, Sa - Samedan, Sl - Schlarigna.

Abb. 2: Tekonische Karte des Arbeitsgebietes mit der Darstellung der verschiedenen Ostalpinen und Penninischen Decken sowie der Spur der Engadinerline (gleiche geographische Lage wie in Abb. 1). Nach FroITZHeIM \& MANATSCHAL (1996), leicht abgeändert. 


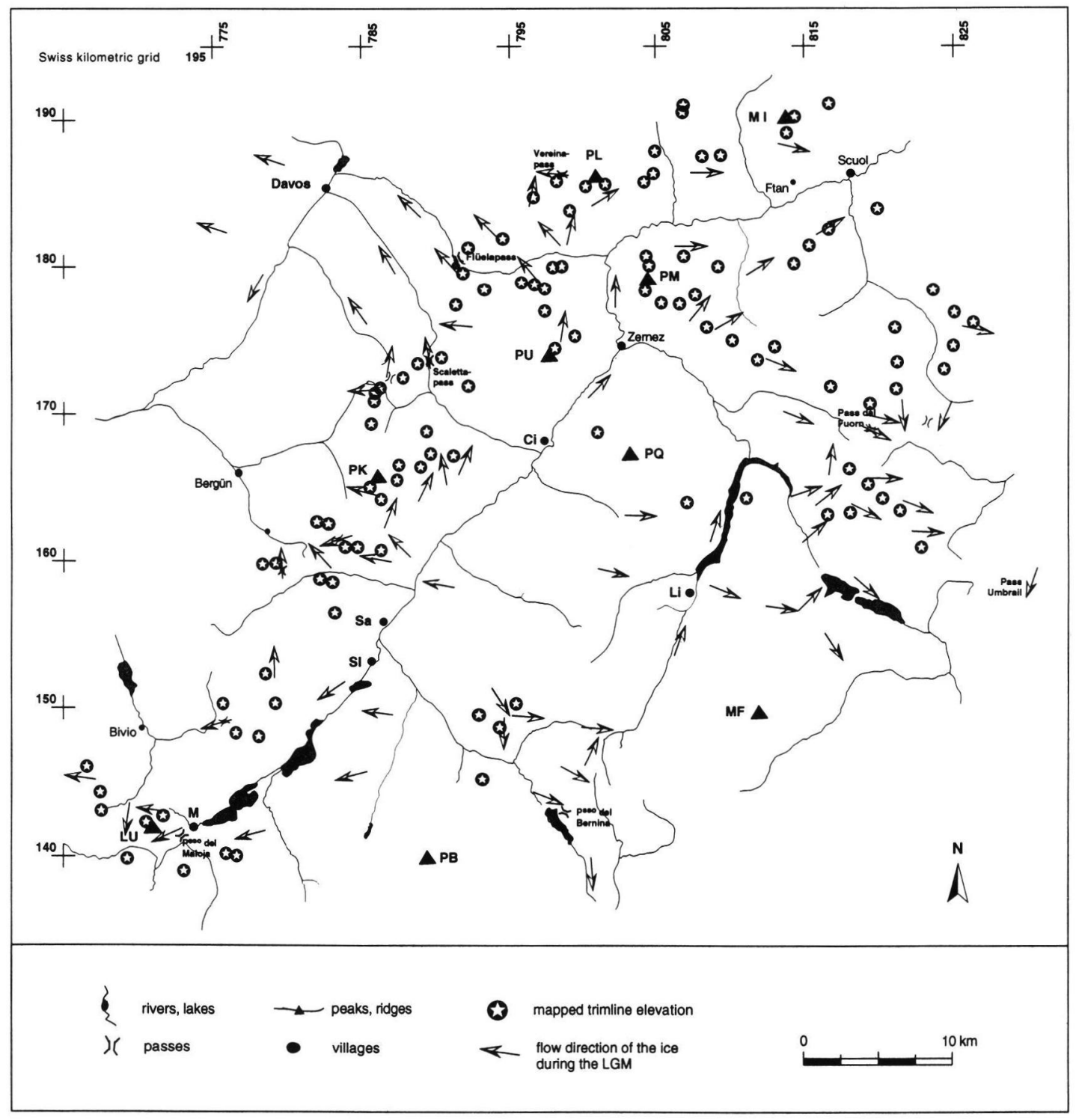

Fig. 3: Schematic map with the localities of measured paleoglaciological features for LGM - trimline position and flow direction. Abbreviations: see Fig. 2.

Abb. 3: Vereinfachte geographische Karte welche die Lage der kartierten paläoglaziologischen Indikatoren für die Fließrichtung und Höhe (Schliffgrenzen) des Eises während des letzteiszeitlichen Maximums darstellt. Vgl. Abb. 2 für die Abkürzungen.

Bernina nappes, exposed more to the east, like diorite, „Saluverbreccie“ and „Juliergranit“ (STAUB 1938, 1951; Corneluus 1951) confirm this flow direction.

North of the En river, in the area between Julierpass $(2284 \mathrm{~m})$ and Vereinapass $(2585 \mathrm{~m})$ glacially-smoothed granitic and gneissic outcrops of the Err-, Bernina, and Silvretta nappe are common up to an altitude of $2850 \mathrm{~m}$. Fine-grained granites show well-preserved striations and glacial polish, but weathering removed these features almost completely from the coarse-grained granites and gneisses. All striations give evidence of the main ice-flow towards northwest and north, with northerly ice-transfluences for all passes north of the En river. The most impressive example of such an ice-transfluence is represented by the pass south of Preda. The surface of this granitic ridge is glacially-moulded and littered with angular blocks of glacially transported local bedrock 
but mostly lacks striations. However, the orientation of the roches moutonnées shows an overflow of the ridge towards the north. Moreover, in some places, detailed plotting of striations clearly illustrates the deviation of the general northerly flow around nunataks, and the pattern of ice deflected around these obstacles. At Piz Kesch for example, ice-flow direction along the western slope is towards the northwest while the flow direction changes from northeastwards in the southeast to northwards in the north at Pass dal Scaletta and Sertigpass; this example illustrates how ice was deflected around nunataks on its way to the north.

The situation is different southeast of Zernez, at Pass dal Fuorn (2149 m), where glacially-smoothed bedrock of the sedimentary S-charl nappe is exposed (Fig. 2). Here, the surface of the widespread dolomitic outcrops suffered granular disintegration and, thus, most of the small-scale glacial erosional features have been removed. In contrast to these carbonates, some few outcrops of Verrucano (Permian sandstones and breccias) preserved striations and can be used to determine former ice-flow. Both chattermarks and striations are rare and mainly restricted to Verrucano outcrops or to recently exposed carbonate outcrops such as the occurrences along the road across Pass dal Fuorn. Scattered crystalline erratics (Juliergranit and Albulagranit) of the Err- and Bernina nappes (DÖsSEgGer 1974) and boulders of a Jurassic breccia originally exposed in the area of Livigno suggest a general flow direction from the west to the east. Combined with the trends of striations and stoss-and-lee-features, this direction indicates that ice flow was formerly across Pass dal Fuorn towards southeast.

At Passo del Bernina (2054 m), south of the En river there is also evidence of overriding by ice. The pass area in cross section has a typical U-shape in the glacially sculptured crystalline bedrock of the Bernina nappe. Evidence of former glacier activity is the numerous striated, polished and grooved surfaces which are found all over, up to an altitude of about $2900 \mathrm{~m}$. West of the pass, at $2600 \mathrm{~m}$ there are two generations of striations which are carved in the fine-grained granite. At the southern end of the glacially eroded basin, presently filled by Lago Bianco, P-forms are found. All features indicate former ice-flow across the pass with a flow direction towards the south. In summary, the reconstruction of flowlines by glacial striae in the area described yield a well defined star-like pattern of former ice flow direction similar to reconstructed flow patterns of the former ice sheets in North America and Scandinavia. The centre from where the ice was able to flow in all directions is assumed to have been in the area between Piz Bernina and Piz d'Urezza.

\section{The trimline}

Trimlines are glacial-erosion features etched into bedrock, marking the maximum erosion level of the former ice body into pre-existing weathered bedrock. They describe the boundary between an ice-moulded downslope area and a frost-affected upslope zone (Thorp 1981; Ballantyne 1990). Depending upon the bedrock lithology, this boundary may be either sharp, occurring within a few meters, or rather diffuse, with a vertical gradual transition zone of 50 to $100 \mathrm{~m}$. From the trimline upwards there are neither erosional nor depositional features. Trimlines are developed best in landscapes with alpine topography where numerous ridges, spurs, arrêtes and steep peaks interrupted the former ice surface as nunataks. Consequently, mapping of trimlines in areas like the Alps provides an excellent, and often the only, evidence for accurate reconstructions of former ice surfaces.

North of the En river a conspicuous trimline occurs on almost all peaks and steep ridges and shows consistent elevations across lithologic and structural breaks. It is best developed and coherent in crystalline bedrock of the Err- and Bernina nappes. South of the En river trimline data are rare because of unfavorable bedrock such as slates and fine-grained sediments. However, a trimline is still visible at Passo del Bernina and in the area of Pass dal Fuorn.

The shape of the former ice surface is best illustrated by plotting the mapped trimline on (a) a SW - NE projection plane representing an $80 \mathrm{~km}$ long transect from Piz Lunghin to Piz Minschun aligned parallel to the Engiadina and (b) on a 35 $\mathrm{km}$ long transect from Flüelapass to Pass dal Fuorn aligned NW - SE, perpendicular to the first transect (Fig. 1). The result (Fig. 4A) shows a continuous rise of the trimline from $2720 \mathrm{~m}$ at Piz Lunghin to $2930 \mathrm{~m}$ at Fcla. Pischa, west of Piz Kesch; it then decreases smoothly to $2810 \mathrm{~m}$ at Piz Linard and further to $2610 \mathrm{~m}$ at Piz Minschun. Between Piz Kesch and Piz d'Urezza, the trimline reaches a maximum altitude of $2880-2930 \mathrm{~m}$. This trend is in agreement with considerations about ice-movement along the Engiadina inferred from the distribution of erratics and measurements of striated bedrock (STAuB, 1938; Cornelius, 1951). 
Fig. $4 \mathrm{~B}$ indicates a rising trimline from $2780 \mathrm{~m}$ in the northwest at Flüelapss to $2820 \mathrm{~m}$ at Piz Mezdi, north of Zernez; it then drops again towards the southeast to $2680 \mathrm{~m}$ at Pass dal Fuorn, suggesting the ice divide lay in the area of Zernez. Other transects aligned NW - SE reveal much the same picture as Fig. $4 \mathrm{~B}$, with a progressive decline in trimline altitude towards the southeast and northwest, away from its maximum elevation of about $2900 \mathrm{~m}$ located right above the bottom of the Engiadina. Again, this trend is consistent with information on ice flow directions inferred from independently mapped glacial erosional features (Spitz \& Dyhrenfurth 1914; Bösch 1937; Heierli 1955).

The intersection of the different transects allows a reconstruction of the regional trend of trimline elevations. As described earlier, the trimline attains its highest elevation of $2950 \mathrm{~m}$ or even more in the area between Piz Bernina and Piz d'Urezza and smoothly slopes northeastward to $2600 \mathrm{~m}$ and southwestward to $2720 \mathrm{~m}$. A steeper decline of trimline elevations is found across the ridges to the northwest and to the southeast. This pattern displays a gradual decline of trimline altitudes in all directions from the centre in the upper part of Engiadina, and is consistent with the conclusions drawn from flowlines determined by striation trends. Again, the reconstruction of the ice surface, when ice stood at the trimline, indicates that there was a high elevation zone in the area enclosed by Piz Bernina, Piz Kesch, Piz d'Urezza, Piz Quattervals and Monte Forcellina (Fig. 3). The ice was drained predominately downstream towards the northeast and up-valley towards the southwest by ice streams but, as documented by striation measurements, it also spilled over the ridges to the northwest and to the southeast of the Engiadina and flowed into the ice streams of the Rhein and Etsch glaciers.

\section{Bedrock morphology}

With the exception of some nunataks, ice age glaciers have reshaped the pre-existing relief to a glacially moulded landscape. The result is the typical U-shaped cross-section of the valleys. Most of the short, steep tributaries end today as hanging valleys because the large longitudinal valleys draining most of the ice experienced much stronger glacial erosion. As far as Engiadina is concerned, all tributaries between Passo del Maloja and Schlarignia are hanging valleys and then again from Cinuos-chel on downstream. Tributaries between Schlarignia and Cinuos-chel however, end at the level of the main valley floor and the lower section of these valleys is characterised by a very small gradient. This is also true for tributaries of Valle di Livigno upstream from Livigno.

Glacial erosion did not only shape the cross-sections, but also modified their longitudinal profiles forming basins and troughs. On a profile of the Engiadina a distinct change in slope occurs at Cinuos-chel (Fig. 4A). Whereas the elevation of the valley floor constantly decreases downstream from Cinuos-chel, it displays a nearly consistent elevation of about $1700 \mathrm{~m}$ on the section between Cinuos-chel and Passo del Maloja, with a step of about $50 \mathrm{~m}$ in the area of Schlarignia and an abrupt end of the valley at Passo del Maloja. The situation along Valle di Livigno with Livigno as a hinge, is even more pronounced.

Several possible interpretations can be made for the reduced basal erosion in particular sections of the valleys mentioned. One explanation is tectonic, as Cinuos-chel and Livigno lie at the boundary between a crystalline nappe (Silvretta and Languard) and a sedimentary nappe (Quattervals nappe). Additionally, this nappe boundary is cut by the younger sinistral transform fault (Engadine line) which runs parallel to the floor of the Engiadina (Fig. 2). Both, the nappe boundary as well as the transform fault may have resulted in differential basal glacial erosion.

Second, the area of reduced erosion formerly may have been covered by ice of a cold based glacier. In this scenario, there would have been no basal erosion as the cold based ice was frozen to its bed and, therefore, permitted no slip between the ice and its bed.

The third interpretation is that it represents an area which was at or beneath the ice divide of a former dome-type glaciation. Observations from regions formerly covered by ice sheets such as North America or Scandinavia show that very little or even no basal erosion may take place below the central part of an ice dome (DENTON \& Hughes 1981).

This third hypothesis is favoured for the following reasons: The occurrence of striated bedrock and chattermarks all over the study area up to the trimline clearly show that the ice was at pressuremelting point, permitting basal sliding even at high altitudes. Therefore, the possibility of cold based ice frozen to its bed can be excluded. The tectonic interpretation also is not very plausible because at Cinuos-chel it is the sedimentary Quattervals nappe which is less eroded than the crystalline Silvretta nappe but at Livigno it is the 


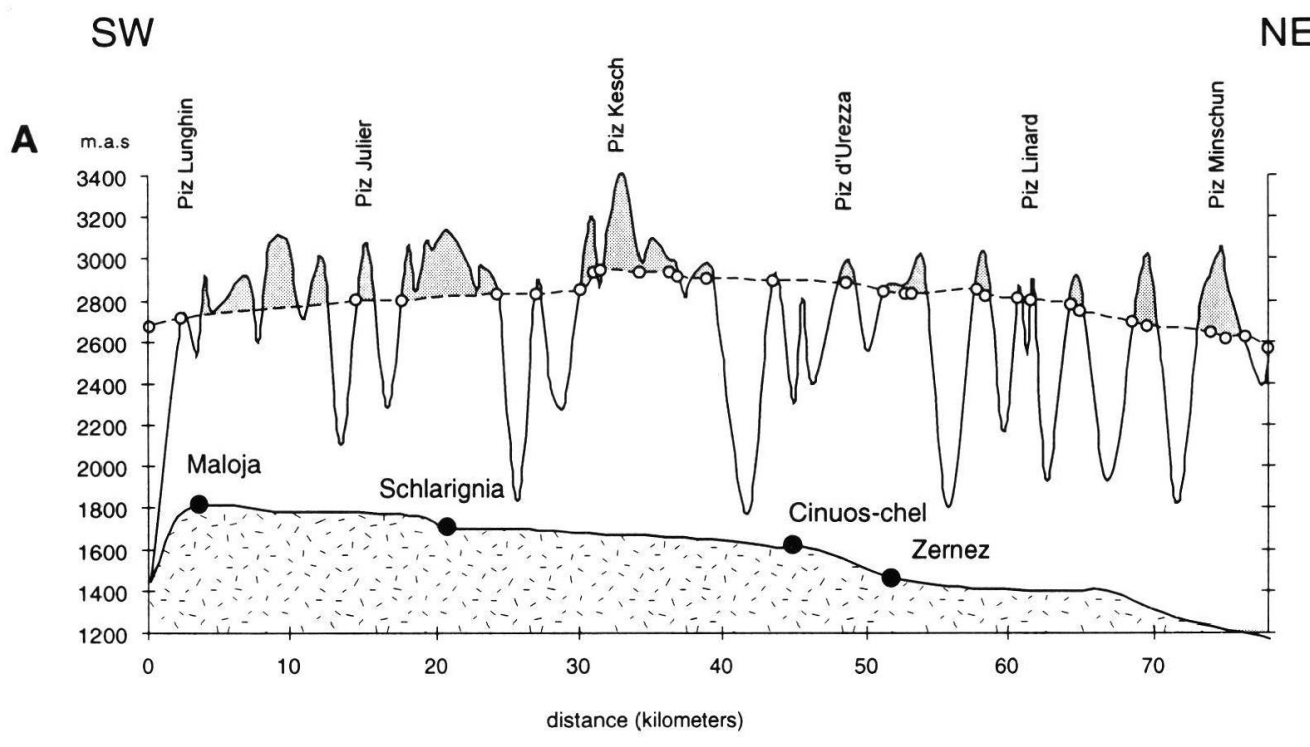

NW SE

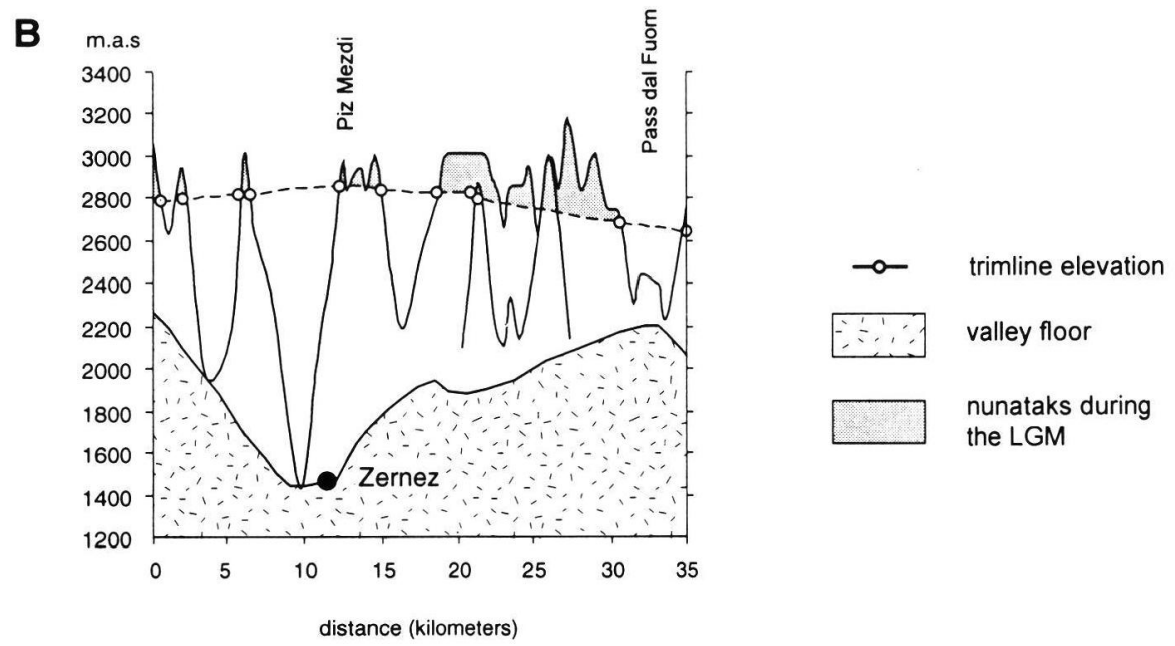

Fig. 4: A) Trimline elevations along a SW - NE transect parallel to the Engiadina valley. Trimline culmination between Schlarigna and Cinuos-chel (vertical exaggeration x 15). B) Trimline elevation along a NW - SE transect from Flüelapass to Pass dal Fuorn. Trimline culmination overhead Zernez, progressively declining northwest- and southeastwards (vertical exaggeration $\mathrm{x}$ 14). Position of transects see Fig. 1.

Abb. 4: A) Schliffgrenzhöhen entlang eines SW-NE-Profiles parallel zum Engadin. Die Kulmination der Schliffgrenze bzw. der Eisoberfläche befindet sich im Gebiet zwischen Schlarigna und Cinuos-chel (15fach überhöht). B) Der Verlauf der Schliffgrenze entlang eines NW-SE-Profiles zwischen Flüelapass und Pass dal Fuorn. Die Schliffgrenze ist am Höchsten über dem Talboden des Engadins in der Umgebung von Zernez und fällt sowohl nach Südosten wie auch nach Nordwesten ab (14fach überhöht). Die Lage der Profilspuren ist in Abb. 1 angegeben. 
opposite. On the other hand the sudden change of inclination (and thus a different erosional strength) can neither come from the Engadine line as this transform fault, normally promoting erosion, does not appear at first at Cinuos-chel, but is present on the whole length form Zernez up to Passo del Maloja. In addition, a similar change of inclination is also found along Valle di Livigno where there is no fault. Moreover, the area of reduced erosion coincides almost perfectly with the area of an ice dome already described by the interpretation of trimline elevations and striation data.

In summary, the results obtained by trimline elevation, the orientation of glacial-erosion features and the bedrock morphology indicate that there was a dome-type glaciation at the LGM in the area described. The trend of trimline elevations show that the ice surface achieved an altitude of $2950 \mathrm{~m}$ to $3000 \mathrm{~m}$ over the area enclosed by Piz Bernina, Piz Kesch, Piz d'Urezza and Monte Forcellina. From this central high area it descended gradually in all directions. Flowlines deduced from striation trends and the distribution of erratics are perpendicular to former ice-surface contours as determined by trimline elevations and confirm the presence of this ice-dome. Finally, the bedrock morphology and the sudden change of inclination along the longitudinal valleys can be explained perfectly by the zone of no erosion lying below a former ice divide, but cannot be explained satisfactorily by tectonics.

\section{Reconstruction of glacier geometry for the LGM by GIS}

In addition to transects with the regional trend of the trimline on well defined projection planes, a three-dimensional ice surface for the whole area has been computed with a geographical information system (GIS). This study describes a first attempt to make use of the techniques for surface modelling and analysis provided by GIS (WEIBEL \& Heller 1991) in order to assist the reconstruction of a three dimensional ice surface of the accumulation area during the LGM.

Modelling of the ice surface by GIS was done as follows: First, a TIN (triangulated irregular network) data model has been computed from the point data containing all mapped field evidence for surface elevation with $\mathrm{x}, \mathrm{y}$ coordinates and $\mathrm{z}$ values and line data representing the digitised contours of the map published by VAN HUSEN (1987). In order to ascertain that the modelling is not affected by „rough“ or inexact data, digitised isolines have been considered only outside the mapped area. A common digital format for representing surfaces in a matrix of equally spaced sample points are digital elevation models (DEM or DTM). A first interpretation of a DEM is referred to as a lattice and therefore the TIN surface data which is based on irregularly spaced point and line data was converted to a lattice. A linear interpolation method was used to calculate missing points inside the triangles. In the last step, this lattice containing the elevation values for a continuous, smooth ice surface was intersected with a digital terrain model (DTM) so as to clip the peaks protruding the ice surface as nunataks.

Fig. 5 shows the ice surface during the LGM as reconstructed by GIS. For clarity, the surface altitude is displayed with contours at intervals of $200 \mathrm{~m}$.

\section{Paleoclimatic implications}

Located in the central part of the Alps, the study area represents a key location concerning atmospheric circulation patterns; this is true not only for the present climate but also for paleoclimates. Consequently, the results provided by the reconstruction of the LGM ice surface in this area are crucial for understanding atmospheric circulation and the precipitation patterns in the period of massive ice build-up from $28000 \mathrm{BP}$ to $23000 \mathrm{BP}$ (SCHLÜCHTER 1991).

Before turning to former climatic conditions, the characteristic precipitation patterns of today's most important weather situations are discussed (Fig. 6).

At present, in the Alps there are two different weather systems responsible for the principal supply of precipitation. Moist air masses from the precipitation-bearing cyclones produced in the North Atlantic are brought to the Alps either by westerly winds across central France or via southern France and northern Italy by the southerly winds (foehn weather situation). The cooling effect of the Alps on the incoming moist air masses causes different precipitation patterns, either with elevated precipitation in the northwest and a precipitation shadow in the south(east), or the opposite. Both of these situations can be observed in the study area: during northwest winds which prevails on more than $50 \%$ of all days, precipitation is highest in the north and northwest of the Engiadina. In contrast, during foehn weather $(25 \%$ of all days) precipitation is highest in the south (Fig 6). The boundary between these two diffe- 


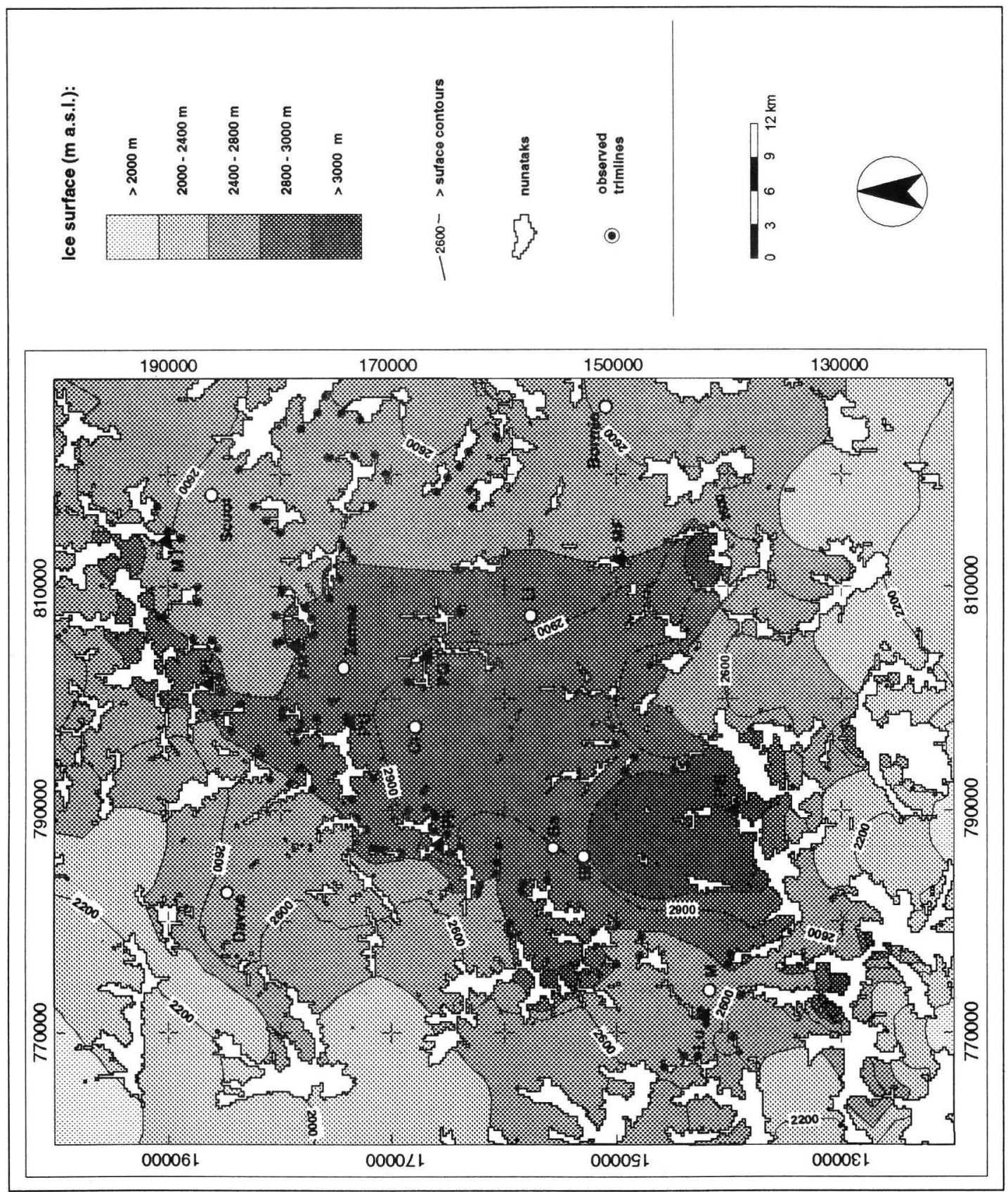

Fig. 5: Three-dimensional of the LGM ice surface in eastern Switzerland and parts of Italy and Austria with contours at $200 \mathrm{~m}$ intervals. The calculations for the GIS supported reconstruction are principally based on mapped trimline elevations. Note the extension of the area with an ice surface altitude above $2800 \mathrm{~m}$, representing the centre of the ice dome. Abbreviations: see Fig. 2.

Abb. 5: Dreidimensionales Modell der Eisoberfläche während des LGM in der Südostschweiz und den Intervallen von $200 \mathrm{~m}$. Die Datengrundlage für dieses, mit Hilfe eines GIS berechneten Modells bilden insbesondere die kartierten Schliffgrenzen. Man beachte die Ausdehnung des Gebietes, dessen Eisoberfläche die Höhe 2800 m übersteigt. Dieses Gebiet stellt ungefähr das Zentrum des Eisdomes dar. Vgl. Abb. 2 für die Abkürzungen. 


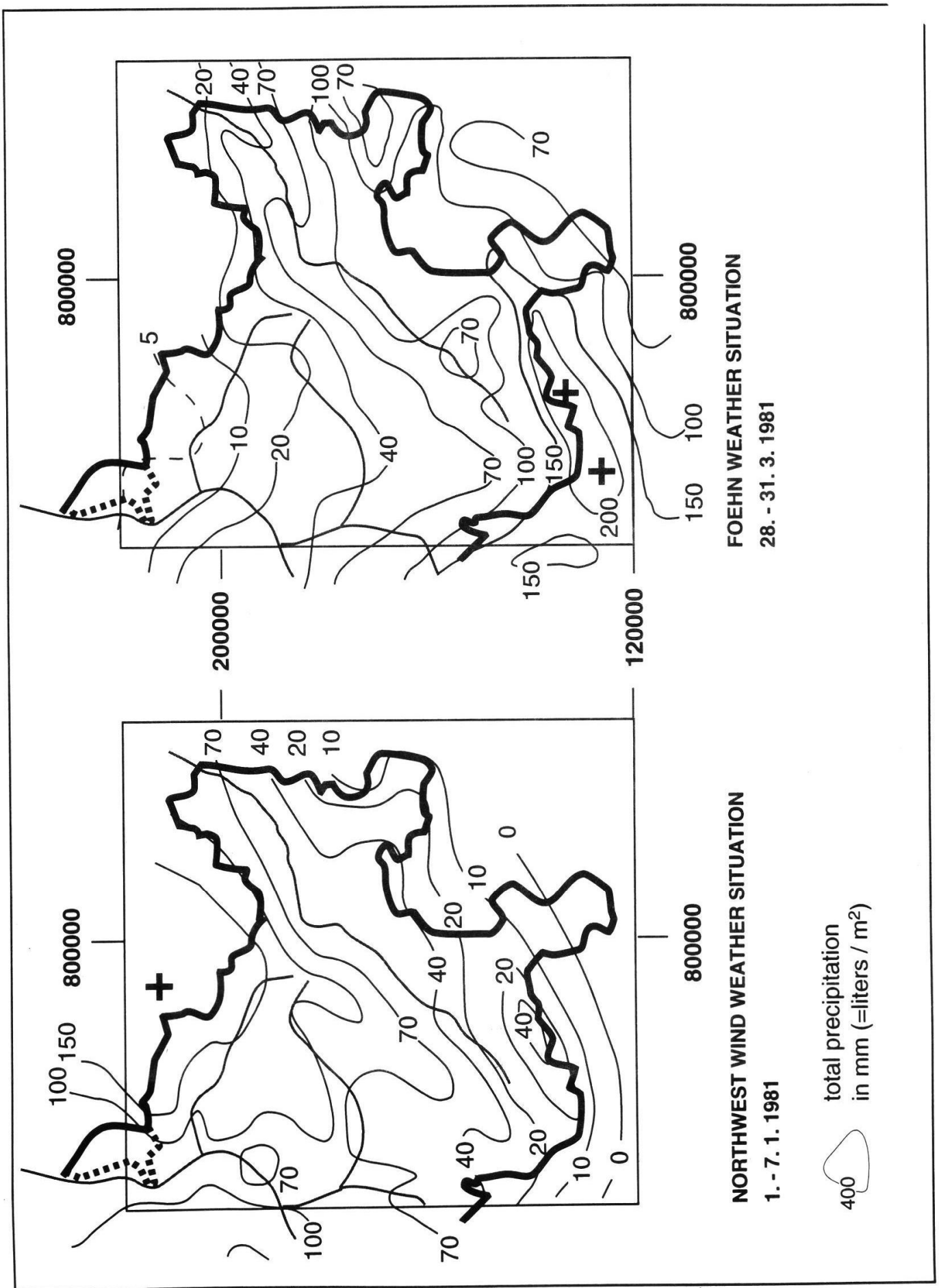

Fig. 6: Precipitation pattern and contours for a) westerly and b) southerly atmospheric circulation in the study area. Modified after Gensler \& SCHüEPp (1991).

Abb. 6: Niederschlagsmuster und Isohyeten für eine ausgewählte a) Westwindwetterlage und b) Südstaulage (Föhn) im Untersuchungsgebiet. Abgeändert nach GENSLER \& SCHÜEPP (1991). 
rent precipitation areas is marked on the precipitation charts by the isoline of $70 \mathrm{~mm} / \mathrm{m}^{2}$ and coincides with the ridge from Julierpass, Piz Kesch, Flüelapass to Pass dal Fuorn. Additionally, there is a distinct difference in the total amount of precipitation. The maximal precipitation values during a typical foehn weather situation are in general locally restricted but significantly higher than during (north-)west weather situations when precipitation extends over a wider area. This is important, when taken into account, as shown in figure 6 , that the former situation lasted only half as long as the latter.

At present westerly circulation is about $50 \%$ more frequent than southerly circulation. From this we may conclude that during about $60 \%$ of all days in an average year the weather in Graubünden is dominated by westerly winds and consequently the total annual precipitation must be considerably higher in the northern parts of Graubünden than in the Engiadina and adjacent valleys to the south.

Prevailing paleocirculation patterns during the last glaciation can be determined by comparing these modern precipitation patterns to the reconstructed Ice Age topography. The configuration of the ice surface has the potential to provide insight into past precipitation patterns and to outline the main precipitation areas. Like the isolines of precipitation, the contours of the ice surface roughly represent the main precipitation areas and approximate the precipitation pattern responsible for the ice build-up, in spite of deformation by ice flow (Fig. 5).

The most striking feature is that the contours of the ice surface computed by GIS and the isolines of foehn weather correspond very well with one another, i.e. the ice surface reaches its maximum altitude in the areas with maximum precipitation due to southerly circulation. On the other hand, there is a marked discrepancy with respect to the isolines of the northwest wind weather conditions. It appears, therefore, that the build-up of the ice was related mainly to precipitation by southerly winds similar to today's foehn. On the contrary, the influence of the westerlies was much less important for precipitation in the Swiss Alps, at least during the last phase of the Würm glaciation. The most reasonable explanation for the dominance of southerly circulation during isotope stage 2 is a displacement of the North Atlantic polar atmospheric front towards the equator due to the advancing margin of pack ice. In such circumstances, the build-up and prevailing tracks of the cyclones likewise moved southwards to a new position south of the Alps; this would have promoted southerly circulation and thus a decline in precipitation away from the southern fringe of the Alps and the development of permafrost conditions in the northern part of the Central Plateau (Fig 7).

The hypothesis presented here was tested further by comparing it to the results from simulations of global ice age atmospheric circulation and climate in the northern hemisphere (KuTzBACH \& Wright 1985; Broccoli \& Manabe 1987; KutzBaCH, et al. 1991). These numerical models show that global climate during the LGM was overwhelmingly dominated by permanent high pressure cells over North America, Greenland, Scandinavia and the British Isles due to the presence of ice sheets. The upper tropospheric westerly jet stream was divided into two branches, one southerly and one northerly, which flowed around both the Laurentide and Eurasian ice sheets. In Eurasia, this anticyclonic circulation with cold northeasterly winds adjacent to the southeastern sector of the ice sheet (MEYer \& KOTTMEIER 1989) played a major part in the development of extensive periglacial areas in Central Europe (WASHBURN 1979; FRENZEL 1991). Such changes of atmospheric circulation were associated with changes in oceanic circulation, and the extent of sea ice increased markedly: For example, the southern limit of permanent pack ice during winters in the North Atlantic reached as far south as $40-50^{\circ} \mathrm{N}$, and $60^{\circ} \mathrm{N}$ during summers (CLIMAP 1976). The displacement of the polar oceanic front southward to the latitude of New York and Spain (Ruddiman, et al. 1980) was accompanied by an equivalent shift of the polar atmospheric front and the associated mid latitude cyclones of about $10-20^{\circ}$; this caused the related storm tracks to move south and to flow from west to east across the Mediterranean. As a result the Mediterranean area and the Southern Alps were subjected to increased rainfall and decreased evaporation (BONATTI 1966; BARTOLAMI, et al. 1977).

Paleowind indicators such as sedimentary structures in Loess sediments (Meyer \& KotTMEIER 1989) and the orientations of dunes (POSER 1948) also have been used to reconstruct past atmospheric circulation in Europe during the LGM. These studies provide additional evidence of anticyclonic circulation in the immediate vicinity of the Eurasian ice sheet, severe periglacial conditions in Central Europe, and a displacement of the main track of the mid latitude cyclones towards 


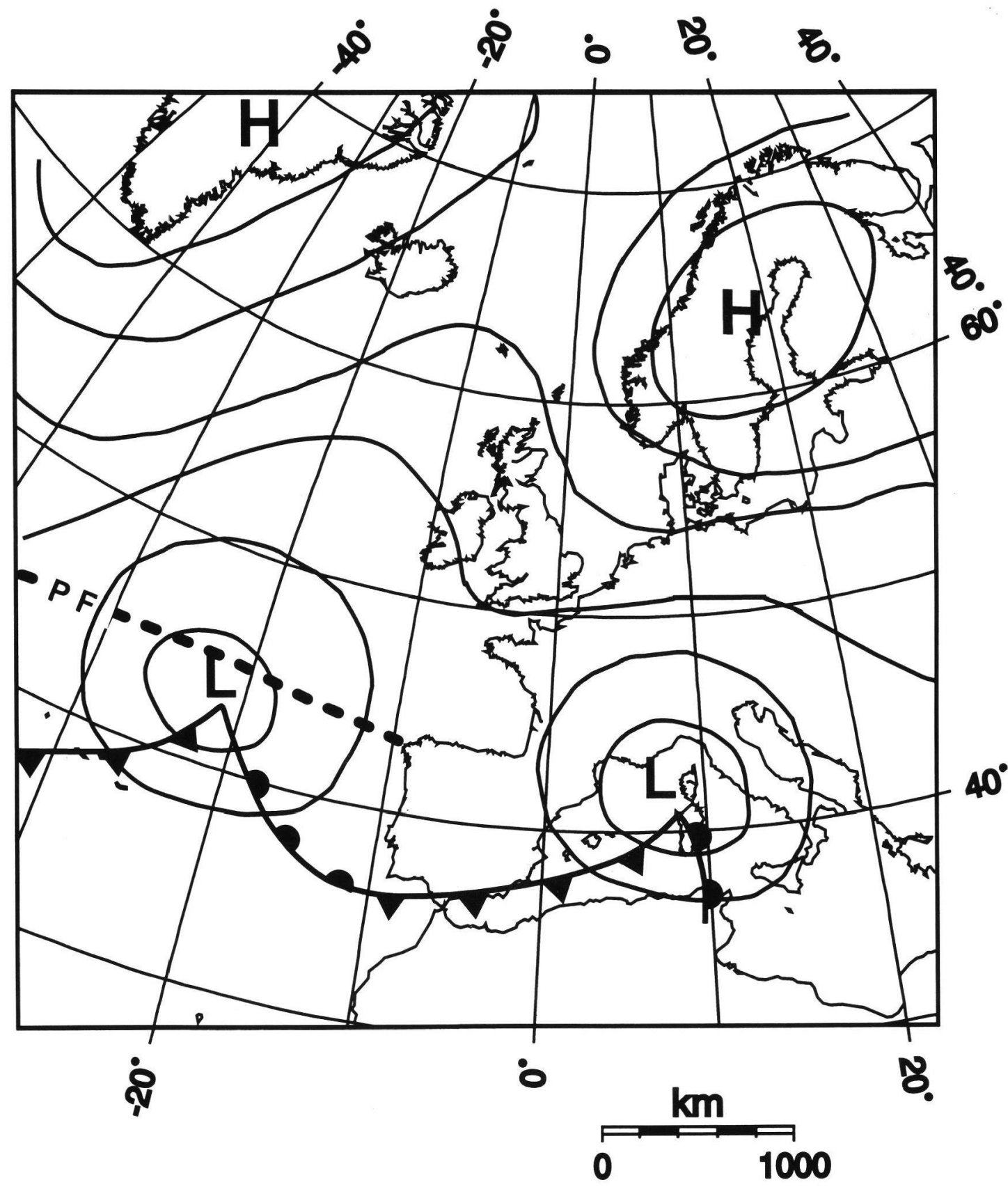

Fig. 7: Assumed characteristics of a typical synoptic weather chart during isotope stage 2. The position of the reconstructed LGM polar atmospheric front (PF) in the North Atlantic during winters according to Ruddiman, et al. (1980). (from Meyer \& KotTMEier 1989).

Abb. 7: Anzunehmende Merkmale einer typischen synoptischen Wetterkarte während des letzteiszeitlichen Maximums (Isotopestufe 2) (nach MeYer \& KotTMEIER, 1989). 
the equator.

Finally, calculations of basal shear stress values and surface velocities of 18 BP Ice Age glaciers in and around the Swiss Alps (Haeberli \& PENz 1985) also indicate climatic conditions south of the Alps which were warmer and more humid than in the north.

\section{Conclusions}

The reconstruction of the ice surface by paleoglaciological field data shows that during the LGM ice poured northward through the passes of Julier, Albula, Scaletta, Füela and Vereina as well as southwards through Pass dal Fuorn and Passo del Bernina. Flowlines derived from glacial erosional features below the trimline, the distribution of erratics and the trends of trimline elevations indicate that the last glacial ice body consisted of a dispersal area with the ice divide situated in the triangle Schlarignia - Cinuos-chel - Livigno and attained a minimum altitude of approximately $3000 \mathrm{~m}$. Bedrock morphology which cannot be explained satisfactorily by tectonic features also supports the reconstruction of an ice dome with radial outflow. A three-dimensional reconstruction of the ice surface using GIS supports the interpretation of this ice dome.

The configuration of the ice surface during the LGM has the potential to provide insight into past climatic conditions and therefore allows the prevailing precipitation pattern which led to the ice build-up to be reconstructed. When modern precipitation patterns are compared with the shape of the reconstructed accumulation area for the LGM, it becomes evident that the configuration of the past atmospheric pressure system during the last glaciation was different to today's, with southerly circulation prevailing at that time. The predominance of foehn is correlated with the southward displacement of the polar atmospheric front that caused the related mid latitude cyclones having tracked eastwards across the Mediterranean. The results from this study fit well with the reported evaluations of paleowind indicators, the results of simulations of global ice age atmospheric circulation as well as calculations of basal shear stress values and surface velocities of Alpine Ice Age glaciers.

\section{Acknowledgements}

This study forms part of my $\mathrm{PhD}$ - thesis undertaken at the University of Berne. Thanks are due to Ch. Schlüchter for many stimulating discussions, comments and suggestions; L. Zgraggen for his constructive criticism and discussions regard- ing the circulation patterns; Ch. Schlüchter, S. Ivy-Ochs and B. Shotyk for their critical reviews that greatly helped to improve the present article. Swiss National Science Foundation grant 2143469.95 supported this work.

\section{Literature}

Ballantyne, C. K. (1990): The Late Quaternary glacial history of the Trotternish Escarpment, Isle of Skye, Scotland, and its implications for ice-sheet reconstruction. - Proceedings of the Geologists' Association, 101: 171-186.

Bartolami, G. C., Fontes, J. C., Markgraf, V. \& Saliege, J. F. (1977): Land, sea and climate in the northern Adriatic region during late Pleistocene and Holocene. - Palaeogeogr. Palaeoclimatol. Palaeoecol., 21: 139-156; Amsterdam.

BinI, A. (1987): L'apparato glaciale würmiano di Como. - Tesi di Dottorato di Ricerca, Università di Milano, $603 \mathrm{p}$.

Blatter, H. \& HaeberLi, W. (1984): Modelling temperature distribution in alpine glaciers. - J. Glaciol., 5: $18-22$.

Bonatti, E. (1966): North Mediterranean climate during the last Würm glaciation. - Nature, 209: 984-985; London.

Bösch, H. (1937): Geologie der zentralen Unterengadiner Dolomiten. - Dissertation, Univ. Zürich, 110 p.

Broccoli, A. J. \& Manabe, S. (1987): The influence of continental ice, atmospheric $\mathrm{CO} 2$, and land albedo on the climate of the last glacial maximum. - Climate Dynamics, 1: 87-99.

Climap, P. M. (1976): The surface of the ice age earth. Science, 191: 4232; 1131-1136.

Cornelius, H. P. (1935): Geologie der Err-Julier-Gruppe: Das Baumaterial (Stratigraphie und Petrographie, exc. Quartär). - Beitr. geol. Karte Schweiz, NF, 70: 1; 1-321; Bern.

Cornelius, H. P. (1951): Geologie der Err-Julier-Gruppe. III. Teil: Quartär und Oberflächengestaltung. Hydrologie. - Beitr. geol. Karte Schweiz, NF, 70: 3; 1-75; Bern.

Denton, G. H. \& Hughes, T. J. (Eds.) (1981): The Last great Ice Sheets.; 484 p.; New York (John Wiley and Sons).

Dössegger, R. (1974): Verrucano und „Buntsandstein“ in den Untenengadiner Dolomiten. - Dissertation, Univ. Zürich, $171 \mathrm{p}$.

Felber, M. (1993): La storia geologica del Tardo-Terziario e del Quaternario nel Mendrisiotto (Ticino meridionale, Svizzera). - Tesi di Dottorato, E.T.H. Zurigo, $617 \mathrm{p}$.

FrENZEL, B. (1991): Das Klima des Letzten Interglazials in Europa. - In: B. Frenzel (Ed.): Klimageschichtliche Probleme der letzten 130000 Jahre. 51-78; Stuttgart (Gustav Fischer Verlag)

Froitzheim, N. \& Manatschal, G. (1996): Kinematics of Jurassic rifting, mantle exhumation, and passivemargin formation in the Austroalpine and Penninic nappes (eastern Switzerland). - Geol. Soc. Amer. Bull., 108: 9; 1120-1133. 
Gensler, G. \& Schuepp, M. (1991): Witterungsklimatologie von Graubünden. - In: H. Elsasser \& M. BOEsch (Eds.): Beiträge zur Geographie Graubündens. 717; Egg/ZH (Fotorotar AG).

Haeberli, W. (1991a): Glazialmorphologische und paläoglaziologische Modelle. - In: M. MOnBARON \& W. Haeberli (Eds.): Fachtagung der Schweizerischen Geomorphologischen Gesellschaft; p. 7-20; Berichte und Forschungen Geographisches Institut Freiburg/CH; 3 .

- (1991b): Zur Glaziologie der letzteiszeitlichen Alpenvergletscherung. - In: B. FrenzeL (Ed.): Klimageschichtliche Probleme der letzten 130000 Jahre. 409-420; Stuttgart (Gustav Fischer Verlag).

- \& Penz, U. (1985): An attempt to reconstruct glaciological and climatological charecteristics of $18 \mathrm{ka}$ $\mathrm{BP}$ ice conditions in and around the Swiss Alps. - Z. Glescherkd. Glazialgeol., 21: 351-361; Innsbruck.

- \& SChlüChter, C. (1987): Geological evidence to constrain modelling of the Late Pleistocene Rhonegletscher (Switzerland). - In: The Physical Basis of Ice Sheet Modelling (Proc. Vancouver Symp., August 1987); p. 333-346; IAHS-Publication No. 170

HantKe, R. (1980): Eiszeitalter. - 703 p.; Thun. (Ott).

Heierli, H. (1955): Geologische Untersuchungen in der Albulazone zwischen Crap Alv und Cinuos-chel (Graubünden), - Dissertation, Univ. Zürich, 106 p.

JÄckLI, H. (1962): Die Vergletscherung der Schweiz im Würmmaximum. - Eclogae geol. Helv., 55: 2; 285294; Basel.

- (1970): Die Schweiz zur letzten Eiszeit. - Karte 1:550000; Atlas der Schweiz, Blatt 6; Bundesamt für Landestopographie; Wabern, Bern

KelLer, O. (1988): Ältere spätwürmzeitliche Gletschervorstösse und Zerfall des Eisstromnetzes in den nördlichen Rhein-Alpen (Weissbad-Stadium/BühlStadium). - Physische Geographie, 27: 241 p.; Zürich.

Kutzbach, J. E., Gallimore, R. G. \& Guetter, P. J. (1991): Sensitivity experiments on the effect of orbitallycaused insolation changes on the interglacial climate of high northern latitudes. - Quaternary International, 10-12: 223-230.

KutzBaCh, J. E. \& Wright, H. E. (1985): Simulation of the climate of 18,000 years BP: results for the North American/North Atlantic/ European sector and comparison with the geologic record of North America. - Quaternary Science Reviews, 4: 3; 147-188; Oxford.

Meyer, H.-H. \& Kottmeier, C. (1989): Die atmosphärische Zirkulation in Europa im Hochglazial der Weichsel-Eiszeit - abgeleitet von Paläowind-Indikatoren und Modellsimulationen. - Eiszeitalter u. Gegenwart, 39: 10-18; Hannover.

Penck, A. \& BrüCKner, E. (1909): Die Alpen im Eiszeitalter. - 1199 p.; Leipzig. (Tauchnitz).
Poser, H. (1948): Aeolische Ablagerungen und Klima des Spätglazials in Mittel- und Westeuropa. - Die Naturwissenschaften, 35: 269-276 and 307-312.

Ruddiman, W. F., Sancetta, C. D., Hiebler-Hunt, V. \& DurazzI, J. T. (1980): Glacial/interglacial response rate of subpolar North Atlantic water to climatic change: the record in ocean sediments. - Quaternary research, 13: 33-64.

- Sancetta, C. D., Hiebler-Hunt, V. \& Drazzi, J. T. (1980): Glacial/interglacial response rate of subpolar North Atlantic water to climatic change: the record in ocean sediments. - Quaternary research; 13: 33-64.

- Sancetta, C. D. \& Mcintyre, A. (1977): Glacial/interglacial response rate of subpolar North Atlantic water to climatic change: the record in ocean sediments. - Phil. Trans. Roy. Soc. London, 280: 119-142.

SCHLÜCHTER, C. (1991): Fazies und Chronologie des letzteiszeitlichen Eisaufbaus im Alpenvorland der Schweiz. - In: B. Frenzel (Ed.): Klimageschichtliche Probleme der letzten 130000 Jahre. 401-408; Stuttgart (Gustav Fischer Verlag).

Spillmann, P. (1993): Die Geologie des penninischostalpinen Grenzbereichs im südlichen Berninagebirge. - Ph.D. thesis, ETH-Zürich, 262 p.

Spitz, A. \& Dyhrenfurth, G. (1914): Monographie der Engadiner Dolomiten zwischen Schuls, Scanfs und dem Stilfserjoch. - Beitr. geol. Karte Schweiz, NF, 44: 1-235; Bern.

Staub, R. (1938): Die Frage einer Schlussvereisung im Berninagebiet zwischen Bergell, Oberengadin und Puschlav. - Eclogae geol. Helv., 31: 1; 125 - 136; Basel.

- (1951): Der Pass von Maloja. - Seine Geschichte und Gestaltung. - Mitt. aus dem Geol. Inst. der ETH und Uni Zürich, 45: 84 .

Thorp, P. W. (1981): A trimline method for defining the upper limit of Loch Lomond Advance glaciers: examples from the Loch Levan and Glencoe areas. Scottish Journal of Geology, 17; 49-64.

TRÜMPY, R. (1960): Zur Geologie des Unterengadins. Ergebnisse der wissenschaftlichen Untersuchungen im Schweizerischen Nationalpark, 12: 71-87.

van Husen, D. (1987): Die Ostalpen in den Eiszeiten. 24 p.; Wien. (Geologische Bundesanstalt Österreichs).

Washburn, A. L. (1979): Geocryology: A survey of periglacial processes and environments. - 406 p.; London. (Edward Arnold Ltd.).

Weibel, R. \& Heller, M. (1991): Digital Terrain Modeling. - In: D. J. Maguire, M. F. Goodchild \& D. W. RHIND (Eds.): Geographical Information Systems: Principles and Applications. 269-297; London (Longman).

Manuskript eingegangen am 2. Juni 1997 